\title{
China's Foreign Direct Investment in Thailand - Current Status and Future Prospects
}

\author{
Mengying Li, Athapol Ruangkanjanases, and Chenin Chen
}

\begin{abstract}
Thailand has great potential to become the investment base to serve as the gateway to ASEAN and world market for Chinese firms. The objectives of this study are: 1) To investigate the attempt of Chinese investors in Thailand; 2) To find out the Chinese investors' current performance; 3) To examine the firm internal factors that impact Chinese investors' current performance; 4) To provide Chinese investors with sustainable investment suggestion. This is a quantitative study. Primary data was collected from 52 Chinese investors while secondary data was collected from previous researches.

This study examines how firm-specific advantages and company profile of firms in host country determine FDI performance basing on the relevant motives' realization till date, future more, they can influent firms' future business plan. The hypotheses are tested empirically based on the conceptual model among Chinese FDI with at least 3 years investment experience in Thailand. The findings suggest that the major motive of China's outflow FDI to Thailand is marketing seeking. Yet, if the Chinese invested firm in Thailand lacks specific advantages, it tends to have a poor performance. Although there are no specific resources can impact the performance significantly. There are several recommendations given based on the analysis.
\end{abstract}

Index Terms-FDI, OLI framework, FSA, RBV, China, Thailand.

\section{INTRODUCTION}

With the repaid growth of Chinese companies, many of them have started to mature into global players and explore the oversea markets. By 2013, there are 89 Chinese companies listed in global fortune 500 [1]. Facing the dramatic changes in home country, more and more Chinese companies also realize it is time for them to move beyond the advantages that they have historically enjoyed: a large domestic market, competitive cost position, and strong state support. Passing the early stage of adaptation, Chinese companies' overseas networks have become increasingly more complicated. In 2012, China's outflow investment was $\$ 168,355.26$ million USD, which accounts for $12 \%$ of the total global outward FDI amount [2].

As Thailand has close cultural and ethnic ties with China and strategic location in ASEAN, in light of the China-ASEAN Free Trade Area (CAFTA), Thailand would play an important role in manufacturing and exporting of Chinese products to ASEAN region. In the1987 to 2012 period, Chinese companies' 347 investment projects in

Manuscript received March 15, 2014; revised May 30, 2014.

The authors are with Chulalongkorn Business School, Chulalongkorn University, Thailand (e-mail: mengying.lain.li@gmail.com, athapol@cbs.chula.ac.th, chenin.c@chula.ac.th).
Thailand valued 102,433.9 million baht and covered all business sectors. China account only $0.78 \%$ of total Thai inward FDI value in 2007. This percentage dramatically increased to $5.29 \%$ in 2012 [3]. China expanded its outward FDI in Thailand by $543.69 \%$ over the past 5 years. Follow the trend of the growth, China will play a more and more important role in inward FDI of Thailand.

On the other hand, inward FDI has been an important driver of Thai economic development. Inward FDI once reached $\$ 7.50$ billion USD and therefore assisted in the process of economic recovery from Asian financial crisis in 1998 [2].

The regional integration of AEC will bring both opportunities and challenges to the ASEAN countries. The importance of FDI as a source of economic growth engine has been recognized by many, thus there is intense competition among ASEAN countries in attracting FDI. In 2012, the most attractive FDI destination is Indonesia (\$19,852.56 million USD), Malaysia $(\$ 10,073.92$ million USD) and Thailand ranked as third with $\$ 8,607.45$ million USD [2]. Exploring the current status of China's FDI status will help the authority to understand the trend of Chinese inward FDI and to create conducive business environment to retain the existing inflows as well as to persuade the remaining to invest.

\section{LITERATURE REVIEW}

\section{A. Concepts of FDI}

According to the IMF and OECD definitions, direct investment reflects an investment made to obtain a lasting interest by a resident entity of one economy (direct investor) in an enterprise that is resident in another economy (the direct investment enterprise) [4]. The definition indicates the long-term commitment and significant influence level by the direct investor on the management of the enterprise. The owner of $10 \%$ or more of a company's capital can be defined as a direct investor [5].

Different investor might have different motives underlying FDI. The motives can be categorized into 4 types: 1) Resource-seeking FDI attempts to acquire particular resources at a lower cost than could be obtained in the home country; 2) Market-seeking FDI attempts to secure market share and sales growth in the target foreign market; 3) Efficiency-seeking FDI attempts to rationalize the structure of established resource-based or marketing-seeking investment in such a way that the firm can gain from the common governance of geographically dispersed activities; and 4) Strategic asset-seeking FDI attempts to acquire the 
assets of foreign firms so as to promote their long-term strategic objectives, especially advancing their international competitiveness [6].

\section{B. Major Theories of FDI}

Stephen Hymer [7] saw the role of firm-specific advantages as a way of marrying the study of FDI with classic models of imperfect competition in product markets. The Monopolistic Advantage Theory demonstrates that FDI occurs largely in oligopolistic industries rather than in industries operating under near-perfect competition. The monopolistic direct investor can enjoy economies of scale, superior technology, or superior knowledge in marketing, management and finance.

Buckley and Casson [8] who found the internalization theory demonstrated that transnational companies are organizing their internal activities so as to develop specific advantages, which then to be exploited. In the case that external market fails to provide an efficient environment, enterprises tend to be transfer semi products within the enterprise via FDI rather than to the external markets in order to seek to maximize overall profits.

The eclectic paradigm, which is also known as the OLI Framework, developed by professor Dunning offers a general framework for explaining international production. The idea behind the Eclectic Paradigm is to integrate isolated theories of international economics into one approach. There are 3 important factors in the structure of theory: firm-specific advantages, location-specific advantages and internalization advantages. A company should obtain all three advantages before it conducts FDI [9].

Production life cycle (PLC) theory developed by Raymond Vernon was used to explain theories of FDI made by U.S. companies in Western Europe in the manufacturing industry. It suggests that U.S. FDI is a response to either a reducing lag between innovation and standardization, or to increasing consumer preferences for new standardized products [10].

Uppsala model is used to explain the pattern of firm's oversea expanding. Uppsala model address that firms first gain experience from the domestic market before they move to foreign markets, then firms start their foreign operations from culturally and geographically close countries and move gradually to culturally and geographically more distant countries [11].

With consideration that the mainstream theories on FDI have been built largely on the experience of developed countries investors, it is also important to discuss the extent to which general theories can be applied on emerging countries like China.

Louis T Wells Jr. [12] claimed that there are two pertinent market features in developing countries that force local firms to generate and adapt various innovations to achieve growth. These two features are small market size and the easy availability of low cost labor. Wells put forward the idea that it would be in the best interest of the local firm, as well as the local market, that these firms establish their initial advantages through 'de-scaled manufacturing' or smaller scale of production.

Contrary to Well's earlier propositions, Sanjaya Lall [13] asserted that developing country firms' advantages lie in the fact that they have indigenous knowledge of developing market conditions, rather than in the ability to descale manufacturing technologies to a smaller market.

\section{Research on China's Outward FDI Theories}

Some researchers outline the unique Chinese characteristics concerning the determinants and motivations for outward FDI [14], the active role of the home government [15] or preference for M\&A instead of green field investment [16].While many those studies which focus on those differences argue that the China's approach to OFDI is relatively unique, the majority of related field researchers think that China's outward FDI, generally speaking, can be explained by mainstream theory [17].

\section{Firm-Specific Advantages and Resource-Based View}

Firm-specific advantages (FSA) refer to the advantages derived from specific assets and capabilities which allow it to outperform its competitors. These assets and capabilities can include access to natural resources, such as high grade ores or inexpensive power, or access to highly trained and skilled personnel human resources. New technologies such as robotics and information technology can provide competitive advantage, whether as a part of the product itself, as an advantage to the making of the product, or as a competitive aid in the business process (for example, better identification and understanding of customers) [18].

The resource-based view (RBV) takes an "inside-out" view or firm-specific perspective on firm-specific advantages. Resource-based view (RBV) as the basis for the competitive advantage of a firm lies primarily in the application of a bundle of valuable tangible or intangible resources at the firm's disposal [19]. The VRIS (valuable, rare, costly to Imitate and substitutable) model is used to evaluate the RBV [20].

\section{RESEARCH METHODOLOGY}

\section{A. Conceptual Framework}

The conceptual framework of this study is based on the literature review and previous related studies. The foundation of this study is OLI framework of Dunning. Researching focuses on the "firm-specific advantages of host country" as the firm internal factor to influent firms' performance in Thailand. Future more, the assumption that company profile including industry, entry mode, firm size, years of operation and parent firm ownership can also have certain influence on firms' performances tested. Another assumption that future firm business plan can be predicted by the performance is examined in this study as well. Putting all logics together provides a conceptual model in Fig. 1.

Here, in order to address the status of China's FDI in Thailand, firm performance is evaluated. Yet, to date, no systematic investigation has considered how well research measures performance. Since an international subsidiary might perform a variety of roles within the firms' network, a different measurement might be more appropriate [21]. In line with this argument, considering the difficulties in collecting sensitive data from firms, researcher decided to use the investors' subjective self-judgment of satisfaction level 
matching organizational strategic investment goals to track the performance of FDI.

Based on the conceptual framework, hypotheses of this study are as follows;

H1: The resources and capabilities have positive relation to Chinese investors' satisfaction level.

H2: Firm-specific advantages are positively associated with Chinese FDI investors' satisfaction level.

H3: General company profile factors impact investors' satisfaction level significantly.

H4: Chinese investors' satisfaction level has positive relation to their future business plan in Thailand.

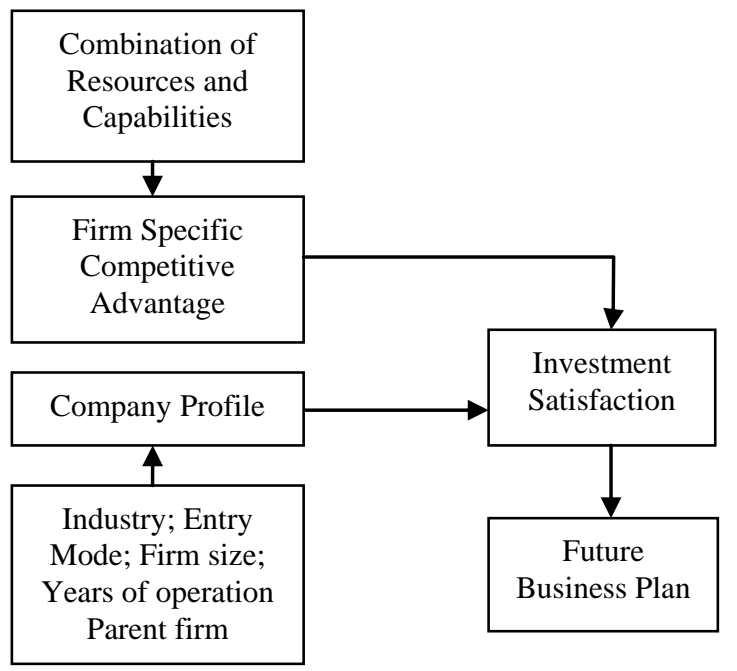

Fig. 1. Conceptual framework.

\section{B. Data Collection}

Primary data was collected by survey. A questionnaire, as a research instrument used in this study, was developed based on the literature review and related studies, and designed to achieve the objectives of the study. It was comprised of four parts: general firm information, motives and satisfaction level for investment, firm-specific advantages and future business Plan in Thailand. According to the formula used by Krejcie \& Morgan in their 1970 article "Determining Sample Size for Research Activities" [22], 165 questionnaires were dispatched. The source of contact information was from BOI website and directory of Chinese enterprises in Thailand. The final number of valid responses was 52 .

\section{Measures}

Weighted scoring model was used to address investors' satisfaction level. First, totally 16 most common motivations were cataloged into 4 aspects according to literature review. All motivations were measured by the five-Point-likert scale with " 1 " as the least relevant and " 5 " as the most relevant. For relevant motives, Chinese investors were required to evaluate their corresponding investment satisfaction level by the five-Point-likert scale with " 1 " as the least satisfied and " 5 " as the most satisfied. The final satisfaction scores were weighted according to the relevant level of the motives of FDI. The equation can be summarized as below:

$$
Y=\beta_{0} X_{0}+\beta_{1} X_{1}+\beta_{2} X_{2}+\ldots+\beta_{n} X_{n}
$$

According to the resource-based view, a bundle of most common valuable tangible or intangible resources at the firm's disposal was listed in questionnaire. The VRIS (valuable, rare, costly to Imitate and substitutable) model was used as measurement with " 1 " as not valuable at all and " 5 " as the most valuable. The resulting model is depicted below:

$$
Y=\left(\sum_{K=0}^{N} X_{K}\right) / N
$$

Firms' future business expansion plan in Thailand included planning business expansion, maintaining current conditions, and planning to downsize.

\section{Independent Variables}

This study employed a number of independent variables in

\begin{tabular}{|c|c|}
\hline & TABLE I: INVESTMENT MOTIVATIONS \\
\hline \multirow{4}{*}{$\begin{array}{l}\text { Resource } \\
\text { seeking }\end{array}$} & Seek and secure natural resources \\
\hline & Seek low-cost or specialized labor \\
\hline & Acquire technological capacity \\
\hline & Access better infrastructure in host country \\
\hline \multirow{4}{*}{$\begin{array}{l}\text { Market } \\
\text { seeking }\end{array}$} & Develop products/services for Thai market \\
\hline & $\begin{array}{l}\text { Identify and exploit new markets for the firms` } \\
\text { finished products }\end{array}$ \\
\hline & Major customer/supplier moved to Thailand \\
\hline & Competitors' presence in Thai market \\
\hline \multirow{4}{*}{$\begin{array}{l}\text { Efficiency } \\
\text { seeking }\end{array}$} & Enjoy a lower cost structure \\
\hline & Risk spreading \\
\hline & Reducing tax burden \\
\hline & Enjoy the economics of scale \\
\hline \multirow{4}{*}{$\begin{array}{c}\text { Strategic } \\
\text { asset seeking }\end{array}$} & Alliances to promote long-term corporate objectives \\
\hline & To build a base for business in south eastern Asia \\
\hline & Acquisition of a reputed brand \\
\hline & $\begin{array}{l}\text { To gain oversea organizational skills (e.g. } \\
\text { management skill, marketing expertise) }\end{array}$ \\
\hline
\end{tabular}
order to define the proxies for the study.

\begin{tabular}{|c|c|}
\hline \multirow{2}{*}{$\begin{array}{l}\text { financial } \\
\text { resources }\end{array}$} & Ability to generate internal funds \\
\hline & ability to raise external capital \\
\hline \multirow{2}{*}{$\begin{array}{l}\text { physical } \\
\text { resources }\end{array}$} & Location of plants, office, and equipment \\
\hline & Access to raw materials and distribution channels \\
\hline $\begin{array}{l}\text { technological } \\
\text { resources }\end{array}$ & $\begin{array}{l}\text { Possession of patents, trademarks, copyrights, and } \\
\text { trade secrets }\end{array}$ \\
\hline \multirow{2}{*}{$\begin{array}{l}\text { organizational } \\
\text { resources }\end{array}$} & Formal planning, command, and control systems \\
\hline & Integrated management information systems \\
\hline \multirow{2}{*}{$\begin{array}{l}\text { human } \\
\text { resources }\end{array}$} & Managerial talents \\
\hline & Organizational culture \\
\hline \multirow{2}{*}{ innovation } & Research and development capabilities \\
\hline & Capacities for organizational innovation and change \\
\hline \multirow{3}{*}{ reputation } & $\begin{array}{l}\text { Perceptions of product quality, durability, and } \\
\text { reliability }\end{array}$ \\
\hline & Reputation as a employer \\
\hline & Reputation as a socially responsible corporate citizen \\
\hline
\end{tabular}

TABLE II: FIRMS' RESOURCES AND CAPABILITIES

The investment satisfaction was measured by several proxies. According to the measurement used in this study, 16 independent variables were used to address the motives of the Chinese investment, while another 16 independent variables were used to record investors' satisfaction level of related motives. The concerned motives listed in Table I were adapted from Peng [18]. Resources and capabilities, listed in 
Table II, were used as independent variables to evaluate the firm-specific advantages of FDI subsidiaries.

Other independent variables used in this study were company profile related variables including industry, entry mode, firm size, years of operation and parent firm ownership, and future business plan variable.

\section{E. Dependent Variable}

Researcher employed two dependent variables in this study. The first dependent variable is a manager's perception of the subsidiary's performance. This variable was measured on a five-point-likert scale. By analyzing managers' satisfaction with the performance of a subsidiary, researcher was in a position to gauge which factors contribute to higher or lower satisfaction with performance. The other dependent variable was firm-specific advantage. This variable was calculated based on firms' resources and capabilities.

\section{DATA ANALYSIS}

TABLE III: NUMBERS AND PERCENTAGES OF THE RESPONDENTS CLASSIFIED BY FIRM DEMOGRAPHY $(N=52)$

\begin{tabular}{|c|c|c|}
\hline & Number & Percentage \\
\hline \multicolumn{3}{|c|}{ 1.1 The primary industry sector company is active in: } \\
\hline Agricultural Products & 10 & $19.23 \%$ \\
\hline Minerals and Ceramics & 4 & $7.69 \%$ \\
\hline Light Industries/Textiles & 8 & $15.38 \%$ \\
\hline Metal Products and Machinery & 9 & $17.31 \%$ \\
\hline Electric and Electronic Products & 8 & $15.38 \%$ \\
\hline Chemicals and Paper & 8 & $15.38 \%$ \\
\hline Services & 5 & $9.62 \%$ \\
\hline \multicolumn{3}{|c|}{ 1.2 Type of investment from Chinese parent organization / shareholder: } \\
\hline Wholly owned subsidiary & 23 & $44.23 \%$ \\
\hline Joint venture & 29 & $55.77 \%$ \\
\hline \multicolumn{3}{|c|}{$\begin{array}{l}1.3 \text { In case of a wholly owned subsidiary, please further specify the type } \\
\text { of investment: }\end{array}$} \\
\hline Green-field investment & 17 & $73.91 \%$ \\
\hline Merger \& Acquisition & 6 & $26.09 \%$ \\
\hline \multicolumn{3}{|c|}{$\begin{array}{l}\text { 1.4 In case of a joint venture, how many voting shares do the Chinese } \\
\text { parent organization / shareholder hold? }\end{array}$} \\
\hline Majority shareholder & 15 & $28.85 \%$ \\
\hline Minority shareholder & 14 & $26.92 \%$ \\
\hline \multicolumn{3}{|l|}{ 1.5 No of employees in Thailand: } \\
\hline$<=50$ & 35 & $67.31 \%$ \\
\hline$>50$ and $<=150$ & 10 & $19.23 \%$ \\
\hline$>150$ & 7 & $13.46 \%$ \\
\hline \multicolumn{3}{|c|}{$\begin{array}{l}\text { 1.6 Year of the (first) investment/acquisition by Chinese parent/share } \\
\text { holder: }\end{array}$} \\
\hline $1975-1991$ & 6 & $11.54 \%$ \\
\hline $1992-1997$ & 12 & $23.08 \%$ \\
\hline $1998-2010$ & 34 & $65.38 \%$ \\
\hline \multicolumn{3}{|c|}{ 1.7 Ownership of the parent organization / share holder in China } \\
\hline Parent organization ownership & 52 & $100.00 \%$ \\
\hline State-owned & 10 & $19.23 \%$ \\
\hline Private & 42 & $80.77 \%$ \\
\hline
\end{tabular}

Results of the conceptual model and research hypotheses were explained. All the collected data is entered and coded for data analysis purpose. The data analyzed statistically via SPSS program and Excel program. Major analysis methods are weighted scoring model, Correlation test and regression model.

The reliability test of Cronbach's Alpha was used to examine internal consistency of the constructs. Nunnaly has indicated 0.7 to be an acceptable reliability coefficient [23], so overall Alpha coefficients 0.753 in this study is an acceptable value.

From the sample of 52 Chinese investors in Thailand, the research findings were concluded and classified into 4 parts as follows;

\section{A. Demographic Data of the Sample}

There are total 52 companies participate the survey. Those companies cover all sectors according to BOI industry segmentation. Among those companies, 23 (44.23\%) companies choose the wholly owned subsidiary (WOS) entry mode. In those WOS projects, 17 (73.91\%) choose Green-field investment and $6(26.09 \%)$ projects enter Thailand by merger \&acquisition. Other 29 (55.77\%) projects partnered with local partners. In question 1.5 , the companies represented in the survey had a workforce that varied from less than 10 to over 500 employees. The average company size is 87 employees. In terms of enterprise age, 34 $(65.38 \%)$ firms have been involved in the investment in Thailand from the year of 1998. In terms of ownership of the parent firm, $42(80.77 \%)$ firms are privately owned and 10 $(19.23 \%)$ firms are state owned. The details are shown in Table III.

\section{B. Motives and Satisfaction Level of Chinese Investors toward FDI in Thailand}

The analysis results of motives and satisfaction level for investment listed in Table IV shows that:

TABLE IV: MOTIVES AND SATISFACTION LEVEL FOR INVESTMENT $(N=52)$

\begin{tabular}{|c|c|c|c|}
\hline Motive & $\begin{array}{l}\text { Weighting } \\
\text { factor }\end{array}$ & $\begin{array}{l}\text { Satisfa } \\
\text { ction } \\
\text { scores }\end{array}$ & $\begin{array}{l}\text { Weig } \\
\text { hted } \\
\text { score }\end{array}$ \\
\hline Resource seeking & $18.94 \%$ & & 0.46 \\
\hline Seek and secure natural resources & $6.69 \%$ & 2.69 & 0.18 \\
\hline Seek low-cost or specialized labor & $5.55 \%$ & 2.42 & 0.13 \\
\hline Acquire technological capacity & $2.29 \%$ & 1.67 & 0.04 \\
\hline $\begin{array}{l}\text { Access better infrastructure in host } \\
\text { country }\end{array}$ & $4.41 \%$ & 2.48 & 0.11 \\
\hline Market seeking & $33.14 \%$ & & 1.02 \\
\hline $\begin{array}{l}\text { Develop products/services for Thai } \\
\text { market }\end{array}$ & $10.53 \%$ & 3.54 & 0.37 \\
\hline $\begin{array}{l}\text { Identify and exploit new markets for } \\
\text { the firms` finished products }\end{array}$ & $12.98 \%$ & 3.17 & 0.41 \\
\hline $\begin{array}{l}\text { Major customer/supplier moved to } \\
\text { Thailand }\end{array}$ & $3.76 \%$ & 1.88 & 0.07 \\
\hline $\begin{array}{l}\text { Competitors' presence in Thai } \\
\text { market }\end{array}$ & $5.88 \%$ & 2.85 & 0.17 \\
\hline Efficiency seeking & $18.45 \%$ & & 0.48 \\
\hline Enjoy a lower cost structure & $3.76 \%$ & 2.58 & 0.1 \\
\hline Risk spreading & $5.06 \%$ & 2.63 & 0.13 \\
\hline Reducing tax burden & $4.33 \%$ & 2.37 & 0.1 \\
\hline Enjoy the economics of scale & $5.31 \%$ & 2.87 & 0.15 \\
\hline Strategic asset seeking & $29.47 \%$ & & 0.94 \\
\hline $\begin{array}{l}\text { Alliances to promote long-term } \\
\text { corporate objectives }\end{array}$ & $9.31 \%$ & 3.17 & 0.3 \\
\hline $\begin{array}{l}\text { To build a base for business in south } \\
\text { eastern Asia }\end{array}$ & $11.84 \%$ & 3.5 & 0.41 \\
\hline Acquisition of a reputed brand & $0.90 \%$ & 1.25 & 0.01 \\
\hline $\begin{array}{l}\text { To gain oversea organizational } \\
\text { skills (e.g. management skill, } \\
\text { marketing expertise) }\end{array}$ & $7.43 \%$ & 2.94 & 0.22 \\
\hline
\end{tabular}

Market-seeking is the dominant motive for investors in our sample. The second important investment motives is strategic asset seeking. Many companies indicate that expanding to Thailand is the first step for the further global business 
development. The third and fourth investment motives focus on the resource seeking and efficiency seeking.

The average weighted satisfaction score of 3.48 indicate investors hold a neutral to somewhat satisfaction level.

\section{Firm-Specific Advantages Evaluation}

According to the mathematical model for firm-specific advantages, the corresponding score is listed in Table V.

The weakest point of Chinese companies in Thailand is reputation with score 2.61 of 5.00. Halls (1993) argues that the reputation of a company and its product/service is the highest potential intangible asset to sustain the firm's competitive advantage [24]. However, for many firms in Thailand, Chinese companies continue to be seen as purveyors of poor quality goods produced at low cost with little concern for employee well-being.

The average score of human resource is 3.40 which is the highest among all resources and capabilities. China is a Confucian culture like collectivism instead of individualism which is close to Thai culture, thus, there is less culture conflict when Chinese investors communicate with local employees.

The average firm-specific advantages score of 2.97 indicates that the assets of Chinese investors are valuable and rate but not substitutable and easy to imitate;

TABLE V: SUMMARY OF FIRM-SPECIFIC ADVANTAGES SCORE $(N=52)$

\begin{tabular}{cc}
\hline \hline Resources and Capabilities & Score \\
\hline financial resources & 3.20 \\
physical resources & 2.80 \\
technological resources & 2.77 \\
organizational resources & 3.23 \\
human resources & 3.40 \\
innovation & 2.80 \\
reputation & 2.61 \\
Firm-specific advantages & 2.97 \\
\hline \hline
\end{tabular}

\section{Hypothesis Testing}

For hypothesis testing, Multiple Regression was used for examining the predictive power of resources-capabilities and overall firm-specific advantages on the overall investment satisfaction to test Hypothesis 1 (H1) and Hypothesis 2 (H2). Pearson's product moment correlation was performed to identify the relationships between company profiles factors and the satisfaction level for testing Hypothesis 3 (H3). Besides, Ordinal Regression was used for examining the relationship between investment satisfaction and future business plan to test Hypothesis 4 (H4) of the study. The hypotheses were tested and concluded as follows;

H1: The resources capabilities have positive relation to Chinese investors' satisfaction level.

Table VI indicates that all resource-capability variables (independent variables) are positively associated with Chinese investors' satisfaction (dependent variable), but none of the variable's impact is statistically significant.

R-Square indicates that $58.4 \%$ of the variance in investors' satisfaction level can be predicted from the variables of firms' resources and capabilities. The p-value (Sig.=0.000)associated with this F value $(F=8.824)$ is smaller than alpha level (typically 0.05), thus researcher can conclude that the independent variables can reliably predict the dependent variable.

The output of the regression can be summarized as equation:

$$
\begin{aligned}
& Y=1.846+0.118 X_{1}+0.061 X_{2}+0.080 X_{3}+ \\
& 0.062 X_{4}+0.073 X_{5}+0.055 X_{6}+0.099 X_{7}
\end{aligned}
$$

where

$Y=$ Investors' satisfaction level

$X_{1}=$ Financial resources and capabilities

$X_{2}=$ Physical resources and capabilities

$X_{3}=$ Technological resources and capabilities

$X_{4}=$ Organizational resources and capabilities

$X_{5}=$ Human resources and capabilities

$X_{6}=$ Innovation resources and capabilities

$X_{7}=$ Reputation

Therefore, Hypothesis 1 was confirmed and supported by regression results.

\begin{tabular}{|c|c|}
\hline \multicolumn{2}{|l|}{ Regression Model } \\
\hline (Constant) & 1.846 \\
\hline financial resources (B) & 0.118 \\
\hline physical resources (B) & 0.061 \\
\hline technological resources (B) & 0.08 \\
\hline organizational resources (B) & 0.062 \\
\hline human resources (B) & 0.073 \\
\hline innovation (B) & 0.055 \\
\hline reputation $(\mathrm{B})$ & 0.099 \\
\hline financial resources (Sig.) & 0.112 \\
\hline physical resources (Sig.) & 0.441 \\
\hline technological resources (Sig.) & 0.127 \\
\hline organizational resources (Sig.) & 0.352 \\
\hline human resources (Sig.) & 0.258 \\
\hline innovation (Sig.) & 0.294 \\
\hline reputation (Sig.) & 0.192 \\
\hline $\mathrm{R}$ & $.764^{\mathrm{a}}$ \\
\hline R Square & 0.584 \\
\hline Adjusted R Square & 0.518 \\
\hline F (ANOVA) & 8.824 \\
\hline Sig. (ANOVA) & $.000^{\mathrm{a}}$ \\
\hline
\end{tabular}

TABLE VI: REGRESSION RESULT FOR HYPOTHESES $1(N=52)$

H2: Firm-specific advantages are positively associated with Chinese FDI investors' satisfaction level.

The firm-specific advantages (CASUM) and investors' satisfaction level (SA) data are plotted in Fig. 2. By looking at this scatter plot, it can be seen that variables $X$ - advantages (CASUM) and $Y$ - investors' satisfaction level (SA) have a 
close relationship which is reasonably represented by a straight line. This would be represented mathematically as:

$$
Y=a+b X
$$

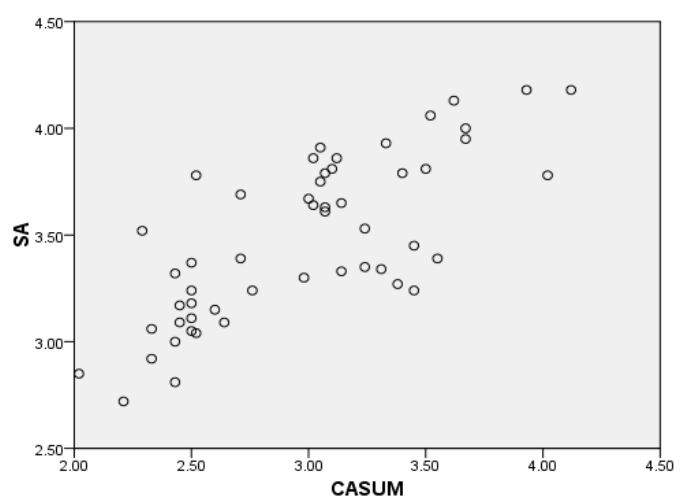

Fig. 2. A scatter plot of the firm-specific advantages (CASUM) and investors' satisfaction level (SA).

From Table VII, the $\mathrm{r}$ value 0.759 in indicates a strong strength of the positive linear relationship between Ownership specific advantages and Chinese investors' satisfaction level. R-Square indicates that $57.7 \%$ of the variance in investors' satisfaction level can be predicted from the overall firms' competitive advantages. Mathematical model can be concluded as:

$$
Y=1.789+0.569 X
$$

where

$Y=$ Investors' satisfaction level (SA)

$X=$ competitive advantages (CASUM)

The influence of firm-specific advantages on investment satisfaction level is both positive and significant. Thus, Hypothesis 2 was supported by regression results.

TABLE VII: REGRESSION RESULT FOR HYPOTHESES $2(N=52)$

\begin{tabular}{|l|r|}
\hline \multicolumn{2}{|l|}{ Regression Model } \\
\hline (Constant) & 1.789 \\
\hline Firm-Specific Advantages (B) & 0.569 \\
\hline Firm-Specific Advantages (Sig.) & $.000^{\mathrm{a}}$ \\
\hline R & $.759^{\mathrm{a}}$ \\
\hline R Square & 0.577 \\
\hline Adjusted R Square & 0.568 \\
\hline F (ANOVA) & 68.143 \\
\hline Sig. (ANOVA) & $.000^{\mathrm{a}}$ \\
\hline
\end{tabular}

H3: General company profile factors impact investors' satisfaction level significantly.

According to Table VIII, among all listed company profile factors, none of the factor has significant impact on the overall investors' satisfaction level. So hypothesis 3 is not supported by the analysis.

According to Table IX, for industry factor, the least satisfied industry is metal products and machinery, the average satisfaction level for 9 interviewed companies is 3.27. The highest satisfaction score 3.59 is from agricultural products sector. In terms of mode of entry, wholly owned subsidiary owns 0.02 point advantages over Joint venture. For years of operation, the data shows the longer a firm operates in Thailand, the more likely the firm satisfied for the business performance. Although, state-owned companies hold bigger competitive advantages, it shows that private firm investors tend to enjoy a higher satisfaction level.

TABLE VIII: CORRELATION ANALYSIS RESULT FOR HYPOTHESES $3(N=52)$
\begin{tabular}{|l|l|}
\hline Variables & Correlation (Sig.) \\
\hline Industry & $-0.128(0.366)$ \\
\hline EntryMode & $-0.029(0.839)$ \\
\hline Shareholding & $-0.011(0.939)$ \\
\hline No. of Employee & $0.071(0.617)$ \\
\hline Years of operation & $0.204(0.146)$ \\
\hline Parent organization ownership & $0.076(0.594)$ \\
\hline
\end{tabular}

TABLE IX: DEPENDENT VARIABLES SUMMARY BASED ON COMPANY

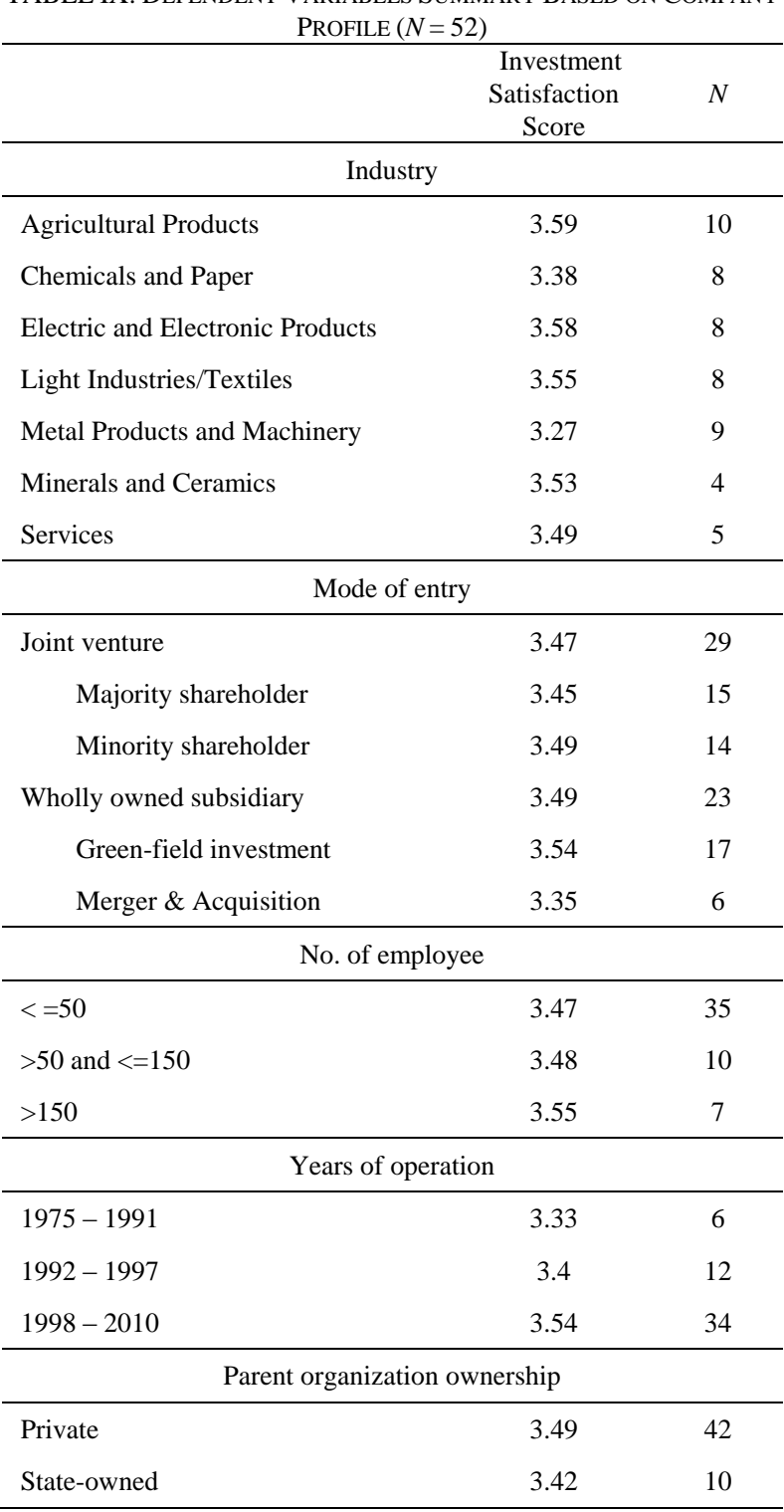

H4: Chinese investors' satisfaction level has positive relation to their future business plan in Thailand. 
According to TABLE X, p value (Sig.) of Goodness-of-Fit table is larger than 0.05 , which suggests that the model is consistent with the fitted model very well. The pseudo R2 values $($ Nagelkerke $=46.1 \%)$ indicates that investment satisfaction level explains a relatively large proportion of the investors' future business plan. Under $95 \%$ confidence interval of the coefficients, all future business plan options show significant association with the investment satisfaction level. Thus, hypothesis 4 is supported by the analysis.

TABLE X: ORDINAL REGRESSION ANALYSIS RESULT FOR HYPOTHESES 4 ( $N$

\begin{tabular}{|l|c|c|}
\hline \multicolumn{1}{|c|}{ Future business plan } & $N$ & $\begin{array}{c}\text { Marginal } \\
\text { Percentage }\end{array}$ \\
\hline Planning business expansion & 26 & 0.5 \\
\hline Maintaining current conditions & 20 & 0.385 \\
\hline Planning to downsize & 6 & 0.115 \\
\hline Sig. (Goodness of fit test) & 0.994 & \\
\hline Nagelkerke & 0.461 & \\
\hline $\begin{array}{l}\text { Planning business expansion } \\
\text { (Parameter Estimates Sig.) }\end{array}$ & .000 \\
\hline $\begin{array}{l}\text { Maintaining current conditions } \\
\text { (Parameter Estimates Sig.) }\end{array}$ & .000 \\
\hline $\begin{array}{l}\text { Planning to downsize (Parameter } \\
\text { Estimates Sig.) }\end{array}$ & .000 \\
\hline
\end{tabular}

\section{DISCUSSION}

The data of motives of Chinese investors in Thailand was collected in this study. Though many researchers believed that China's firms conduct outward FDI to seek for natural resources, but, in the feedback of survey, the market seeking and resource seeking did play an important role in motives of China's investment to Thailand. With the development of the business plan of China's investors, we could see more and more investors started to pay attention to strategic asset seeking and efficiency seeking. This could be considered as the evolution of China's outward FDI. Investors start to move from immediate revenue generated from oversea sells and resource purchasing to a long term strategic development involving strategic asset. The deeper integration with local economy makes China's investment motives more and more complicated.

According to the analysis of hypotheses 3 , no company profile factor could impact investors' satisfaction level significantly. Because the measurement used to evaluate firm performance is satisfaction level, SME may have higher score than that of MNE. However, the finance performance may differ. The overall satisfaction level which is impacted by company profile indicates that there is no specific entry mode, shareholding percentage, years of operation and ownership of the parent organization can lead the company to success in doing business in Thailand. So the success of the outward FDI heavily depends on the firm internal factors.

This study also examined the influences of firm-specific advantages on performance of the overseas subsidiaries. The empirical research provides supportive evidence to the hypotheses 1 and hypotheses 2 . Among all firms' specific resources and capabilities, financial resources and capabilities $\quad(B=0.118), \quad$ reputation $\quad(B=0.099), \quad$ and technological resources and capabilities $(B=0.080)$ contribute more significant influence on investors' satisfaction level comparing to other resources and capabilities. The least important factor is innovation resource and capability.

A possible explanation for these findings; For financial resources and capabilities, as Chinese companies gather pace to go overseas, there is a huge demand for diversified, integrated financial services such as corporate finance, investment banking and financial intermediary, in addition to conventional services like deposit, loan and settlement. The bias of the domestic financial system towards state-owned firms and investments is pronounced when it comes to overseas financing, especially smaller firms from China's private sector that struggle to raise financing for overseas projects. Internal financial resource from parent firm is often utilized by the overseas subsidiaries in Chinese outward FDI. The average resources and capabilities score of 3.20 shows that Chinese investors have confidence in the ability of raising fund by far. For innovation resources and capabilities, Chinese firms have special knowledge of developing country markets and the technology which is suitable for developing consumer rather than of the frontier-moving or innovative type. However, many other factors heavily impact the performance of the firm. For example, due to the low price low quality image of Chinese products, Thai consumers have second thoughts for innovative products from China. The overall innovation resources and capabilities score is only 2.8 .

As proved by hypotheses 4, the overall investors' satisfaction level can significantly impact the future business in Thailand. During the interview, many investors express their interest in increasing the investment amount in Thailand. But there are also some political stability concerns hold investors back. Another concern for Chinese investors is the proper size of investment, some companies enjoy the booming of the sales, but while expanding the business in Thailand, they also take a higher risk. Many companies have not prepared themselves to a deeper integration.

\section{RECOMMENDATION}

From firm internal resource and capability respect, there are several recommendations can be shared based on this study to help Chinese investors to achieve sustainable business development in Thailand.

Financial resources: Besides increasing the internal financial generation capability, leveraging external financial consulting service could help firm to overcome the financial problem in overseas operation. Chinese firms also need to accelerate the learning curve of their overseas businesses.

Physical resources: joint venture or M\&A can help Chinese firm to access the limited physical like land or sourcing/distribution channel. However partner up with local business partner should help firm to achieve the goal with less risk.

Technological resources: Chinese firm need to understand the value and importance of intellectual property in overseas market. Meanwhile, Chinese firm need to improve the ability in generating patents and the ability to translate patents into economic value. 
Organizational resources: Many Chinese firms should have clear division of work and job description. Thus, firm need to setup a clear reporting system and integrated management information channel. It requires the long-term united efforts of leaders in a strategic hierarchical level and high organizational maturity.

Human resources: Firms sometimes assign home-country nationals from the headquarters' staff abroad on the assumption that these managers are more steeped in the firm's policies and culture and more likely to unquestioningly implement headquarters' instructions. Although it's important of headquarters have certain control over subsidiaries, firm also need to develop top managers in host country. China's culture is close to Thai culture. Firm can easily find local talent who share similar value system and able to understand the headquarter culture.

Innovation: Although some Chinese firms have laid their attention on innovation, where Chinese firms still have a lot of catching up to do in general is in making adjustments based on customer feedback after a product hits the market, bringing a new product to market rapidly and improving its quality. Though many firms have very limited innovative capability, they still can access innovative technology via spillovers from academic, publicly funded research and other open R\&D sources.

Reputation: It is a long term engagement to form a firm's reputation. The growing importance of web-based participatory media and declining trust in advertising are promoting wider, faster scrutiny of companies and rendering traditional public-relations tools less effective in addressing reputational challenges. Chinese investors need to enhance their listening skills so that they are sufficiently aware of emerging issues. Doing something effectively means stepping up both the sophistication and the internal coordination of reputation efforts.

\section{LIMITATION OF THE STUDY}

Although this study may provide insight into the resource-capability framework, in particular the resource/capability - competitive advantage - investors' satisfaction level relationship, it has many limitations.

First, this study employed a survey over a short period of time. So this study does not fully explore the paths within the firms' growth history in Thailand. The firms' past behavior may present guide and constrain to its future behavior and other firms can take the experience as reference.

The second limitation is in regard to respondents. Although all respondents were Chinese investors, thus the collected data are therefore believed to be accurate, but the feedback rate is low. Many researcher counter similar issues when they investigate Chinese oversea investment. The research in the characteristic of firms which do not reply the survey may help to have a complete understanding of China's outward FDI.

\section{FUTURE RESEARCH}

In this paper the researchers have provided a systematic analysis of the investors' satisfaction level and firm-specific advantages of China's outward FDI in Thailand, using both primary data and secondary data. In addition, the researchers have made an attempt to uncover the connection of investors' satisfaction level and the firms' resources and capabilities of China's outward FDI by estimating equation. However, the number of Chinese investors included in the sample we used in estimating China's outward FDI in Thailand is substantially smaller than the full sample of 165 Chinese investors. Thus, the first direction of research is to expand the sample size. A second direction of further research is to consider the impact of other potential factors that could have an impact on China's outward FDI from instructional based view.

\section{REFERENCES}

[1] CNN Money. (2013). A New perspective on the corporate world Fortune Magazine. [Online]. Available: http://money.cnn.com/ magazines/fortune/global500/2012/global-company-growth/

[2] UNCTAD. (2013). FDI/TNC database. [Online]. Available: http//:www.unctad.org/fdistatistics

[3] BOT. (2013). Foreign direct investment classified by country. [Online]. Available: http://www.bot.or.th/ STATISTICS

[4] IMF, Balance of Payments Manual, 5th edition, International Monetary Fund, Washington: International Monetary Fund, p. 86, 1993.

[5] OECD, Benchmark Definition of Foreign Direct Investment, Washington: International Monetary Fund, p. 17, 2008.

[6] J. H. Dunning, Multinational Enterprises and the Global Economy, Wokingham, Addison Wesley, Reading, MA., p. 20, 1993.

[7] S. Hymer, "The international operations of national firms: A study of direct foreign investment," Doctoral Dissertation MIT, Cambridge, MA, p. 253, 1960.

[8] P. J. Buckley and M. C. Casson, The Future of the Multinational Enterprise, 25th anniversary edition, London: Macmillan, p. 122, 1976.

[9] J. B. Barney, "Firm resources and sustained competitive advantage," Journal of Management, vol. 1, pp. 99-120, 1991.

[10] R. Vernon, "International investment and international trade in the product cycle," The Quarterly Journal of Economics, The MIT Press, vol. 80 , no. 2 , pp. 190-207, 1966.

[11] A. Blomstermo and D. D. Sharma, "Learning in the internationalisation process of firms," in International Marketing Review, E. Elgar, Ed. 2003, p. 261.

[12] L. T. Wells Jr., Third World Multinationals: The Rise of Foreign Investments from Developing Countries, Cambridge: MIT Press, 1983, pp. $2-10$.

[13] S. Lall, The New Multinationals: The Spread of Third World Enterprises, New York: John Wiley \& Sons, 1983, pp. 5-27.

[14] W. He and M. A. Lyles. "China's outward foreign direct investment," Business Horizons, vol. 51, issue 6, pp. 485-491, 2008.

[15] M. Y. Wang, "The motivations behind china's government-initiated industrial investments overseas," Pacific Affairs, vol. 75, no. 2, pp. 187-206, 2002.

[16] J. Zhang and C. Zhou, "A study on institutional barriers of Chinese companies going global," Economic Research Journal, vol. 45, no. 6, p. $80,2010$.

[17] Z. Wei, "The literature on Chinese outward FDI," Multinational Business Review, vol. 18, no. 3, pp. 73-112, 2010.

[18] W. M. Peng, Global Business, Cengage Learning, 2008, pp. 161-183.

[19] E. T. Penrose, The Theory of the Growth of the Firm, New York: Oxford University Press, 1959, p. 272.

[20] J. B. Barney and W. S. Hesterly, Strategic Management and Competitive Advantage, New Jersey: Pearson, 2010, pp. 68-86.

[21] E. Tatoglu and K. W. Glaister, "An Analysis of Motives for Western FDI in Turkey," International Business Review, vol. 40, no. 3, pp. 279-314,1998.

[22] R. V. Krejcie and D. W. Morgan, Determining Sample Size for Research Activities, Educational and Psychological Measurements, 1970, pp. 607-610

[23] J. C. Nunnally, Psychometric Theory, 2nd ed. New York: McGraw-Hill, 1978, p. 245.

[24] R. Hall, "A framework linking intangible resources and capabilities to sustainable competitive advantage," Strategic Management Journal, vol. 14 , no. 8 , pp. $607-618,1993$. 
Mengying $\mathbf{L i}$ is a student with the master of management program in International Business, Chulalaongkorn Business School, Chulalongkorn University. She worked as an ERP implementation specialist for 2 years after obtaining bachelor degree in e-commerce at Shanghai Sanda University in 2010. Upon completion of master's program, she has decided to further her studies in management and informatics field.

Athapol Ruangkanjanases is a faculty member at the Department of Commerce, Chulalongkorn Business School, Chulalonglorn University. He received his Ph.D. degree from Illinois Institute of Technology, USA. Before joining Chulalongkorn University, he taught at School of Management, Marist College, New York, USA.
Chenin Chen is an adjunct associate professor at Chulalongkorn Business School, Chulalonglorn University. He received his D.B.A. degree from United States International University, California, USA. He is the managing director of Rayong Wire Industries Public Company Limited and board director of Capital Engineering Network Public Company Limited and UaWithya Public Company Limited; all are listed companies in Stock Exchange Market of Thailand. 